\title{
An empirical study of lean production in the ceramic tile industry in Spain
}

\author{
Tomas Bonavia
}

Department of Social Psychology, University of Valencia, Valencia, Spain, and

Juan Antonio Marin

Department of Business Administration, Polytechnic University of Valencia, Valencia, Spain

\begin{abstract}
Purpose - To determine the degree of use of some of the most representative lean production (LP) practices in the Spanish ceramic tile industry, their relationship with plant size and their effect on the operational performance of the companies in the sector.

Design/methodology/approach - A questionnaire was developed for data collection. Findings are presented from 76 companies (79.17 per cent of the total sample) that specialise in single firing ceramics.

Findings - In the sector under study, there is one set of practices that have as yet scarcely been implemented (group technology, kanban, reduction of set-up time, development of multi-function employees and visual factory) and another set whose use is fairly widespread (standardisation of operations, total productive maintenance and quality controls). The degree of their respective use depends on a firm's size. Very few correlations appear between the degree of use of any specific LP practice in isolation and the operational indicators.

Research limitations/implications - For certain variables we found very little variation between the firms in our sample. Moreover, many firms did not have available the data needed for calculating capacity utilisation, and hence we have not been able to check its effects in our analysis.

Practical implications - The paper presents data for reflecting on the application of different LP practices in isolation and on the impediments limiting the use of some of them in the sector.

Originality/value - The paper extends the work of other researchers by focusing on a sector and a country that have been very little studied until now. The sample consists of a set of firms that are fairly homogeneous; this facilitates analysing the relationships between the selected variables while keeping other variables controlled.
\end{abstract}

Keywords Lean production, Ceramics, Small to medium-sized enterprises, Business performance, Spain Paper type Research paper

\section{Introduction}

Since, the 1980s, numerous businesses in various sectors of industry have continually been introducing programmes intended to improve both productivity and quality (Cua et al., 2001; White and Prybutok, 2001). Several authors have posited lean production (LP) as the best possible production system and one that can be

This work was carried out with the support of the Ministry of Culture and Education of the Valencian Regional Government (GV00-013-7). The authors would like to thank the Foreign Language Co-ordination Office at the Polytechnic University of Valencia for their help in translating this paper. 
IJOPM

26,5

506 implemented in any company. This idea is supported both by those who first devised the system, at least in its American version (Womack et al., 1990; Womack and Jones, 1996), and by their supporters, e.g. Krafcik (1988), Lee (1997), MacDuffie (1995) and Sohal and Egglestone (1994). Moreover, the foreword to the Spanish edition of Womack et al. (1990) claims for LP, that:

... although we have taken the automobile industry as an example ..., it may be applied to all industries in Spain... Spain, with a relatively young workforce and many new plants, sets out with an advantage compared to the rest of Europe (the underline is ours).

It seems these ideas have had a certain degree of acceptance in our country, although with slight differences. Martínez Sánchez and Pérez Pérez (2001) shows that LP is not in fact an unknown phenomenon in Spain, at least in the automobile and machine manufacturing industries. Nevertheless, the paper confirms that most of the LP indicators appear more in large companies than in small- and medium-sized enterprises (SME). Other authors too have emphasised the need to study the implications of LP for SMEs (Karlsson and Ahlström, 1997; Lee, 1997; White et al., 1999).

On the other hand, not all opinions are favourable to LP. For one thing LP is not so efficient as was once thought (Williams et al., 1992), nor is it the only alternative (Cooney, 2002). Furthermore, the benefits of using individual practices in isolation are not clear (Fullerton and McWatters, 2001; Sakakibara et al., 1997; White and Prybutok, 2001). Consequently, there is a need, as seen by Shah and Ward (2003), to broaden empirical research in the direction of determining the performance implications of implementing LP practices and analysing data from a set of firms that are all in the same sector.

It is typical of the environment in which most industrial enterprises operate today that there is ever-increasing competition, faster change and fluctuating demand. Most markets are mature and customers demand quality products adapted to their specific needs. One such need is faster and more frequent deliveries (Marín and Delgado, 2000; Suzaki, 2000). This of course affects firms that manufacture ceramic floorings and coverings, especially those in the leading producer countries (Andrés Romano, 2001; Dalmau Porta et al., 1993; Rowley, 1996). Until a few years ago, the main variables in the ceramic tile production processes were energy costs, manpower costs and access to raw material that left little residue (Ybarra et al., 1996). Since, the early 1990s, however, the traditional production problems have been made more complex, which forces a rethink of operations management strategies in the sector (Andrés Romano, 2001). One possibility may be for firms in the industry to turn to LP. For this they can take advantage of a set of clearly defined practices for improving the efficiency of their production systems. Consequently, one would expect some degree of implementation of LP techniques in any sector that is subject to intense competition.

These are the ideas that motivated this research project, to assess the extent to which the ceramic tile industry in Spain uses LP practices. In addition, we hoped to show the effect that applying the most relevant LP practices has on operational performance.

\section{LP concept and practices}

Various terms have been used to denote the set of tools designed to increase business competitiveness by systematically eliminating waste of all kinds (Callen et al., 2000). 
Among them are "just in time" (JIT), "total quality management" (TQM), "world class manufacturing" and "lean production" (Prado Prado, 2002; White and Prybutok, 2001).

"Waste" can be defined as anything beyond the strict minimum needed by way of equipment, materials, components, space or worker time in order to give added value to the goods produced (Marín and Delgado, 2000; Suzaki, 2000). To eliminate it, companies must be more aware of the importance of process continuous improvement, manufacturing times and batch sizes. These actions are basic to the set of techniques that we call "lean production". The complete model of "lean enterprise" includes not only LP (aka "lean manufacturing") but also the activities of "lean product development", "lean procurement" and "lean distribution" (Jackson and Dyer, 1998; Karlsson and Ahlström, 1996; Martínez Sánchez and Pérez Pérez, 2001). However, our research interest focuses on the activities that take place in the manufacturing function, and this will lead us to analyse and describe only these aspects concerning LP. We are nevertheless aware of the difficulties the limitation poses, since the boundaries between the different aspects mentioned are fuzzy (Flynn and Sakakibara, 1995; Williams et al., 1995).

Concentrating then on LP, we find enough agreement for us to identify three "bundles" of associated practices: namely JIT, TQM and "total productive maintenance” (TPM) (Cua et al., 2001; Katayama and Bennett, 1996; Sakakibara et al., 1997). Most authors also include a fourth important bundle, which is "human resource management" (HRM) or "workforce management" (Flynn and Sakakibara, 1995; Forza, 1996; Lowe et al., 1997; MacDuffie, 1995; Shah and Ward, 2003; Smith et al., 2003). However, Sakakibara et al. (1997) are of the opinion that HRM activities are common practices; along with other infrastructure practices like TQM, manufacturing strategy or organisational characteristics that facilitate or limit the implementation of JIT and TPM bundles. Cua et al. (2001) leans the same way, although this author classes TQM too as one of the core bundles. There are also authors such as Fullerton and McWatters (2001) who do not consider HRM activities as practices but rather as outputs after JIT has been implemented.

Just as with the boundaries between the components of lean enterprise, there is no unanimous classification of the tools that make up each of the bundles: TQM, JIT, TPM or HRM (Flynn and Sakakibara, 1995). The associated LP practices may vary in number from 10 to nearly 30 according to which author is consulted. In Table I, we have summarised the most usual ones.

Among the control variables that determine the degree to which these practices are used, the ones most often mentioned are plant size (Cua et al., 2001; Fullerton and McWatters, 2001; Inman and Mehra, 1990; Lee, 1997; Martínez Sánchez and Pérez Pérez, 2001; Schonberger, 1996; Shah and Ward, 2003; White et al., 1999) and type of production process (repetitive/not repetitive) (Cua et al., 2001; De Toni and Tonchia, 1996; Fullerton and McWatters, 2001; White et al., 1999). We will comment in more depth on the effect of plant size in the next section. The aspects related to type of production process will be commented on briefly in various sections of this paper where we describe the ceramic tile industry and expound our hypotheses.

\section{LP and plant size}

Some authors call for more research into the LP implementations in small manufacturing firms (Karlsson and Ahlström, 1997; Lee, 1997). For one thing, the
An empirical study of lean production

507 
IJOPM

26,5

508

Table I.

LP practices

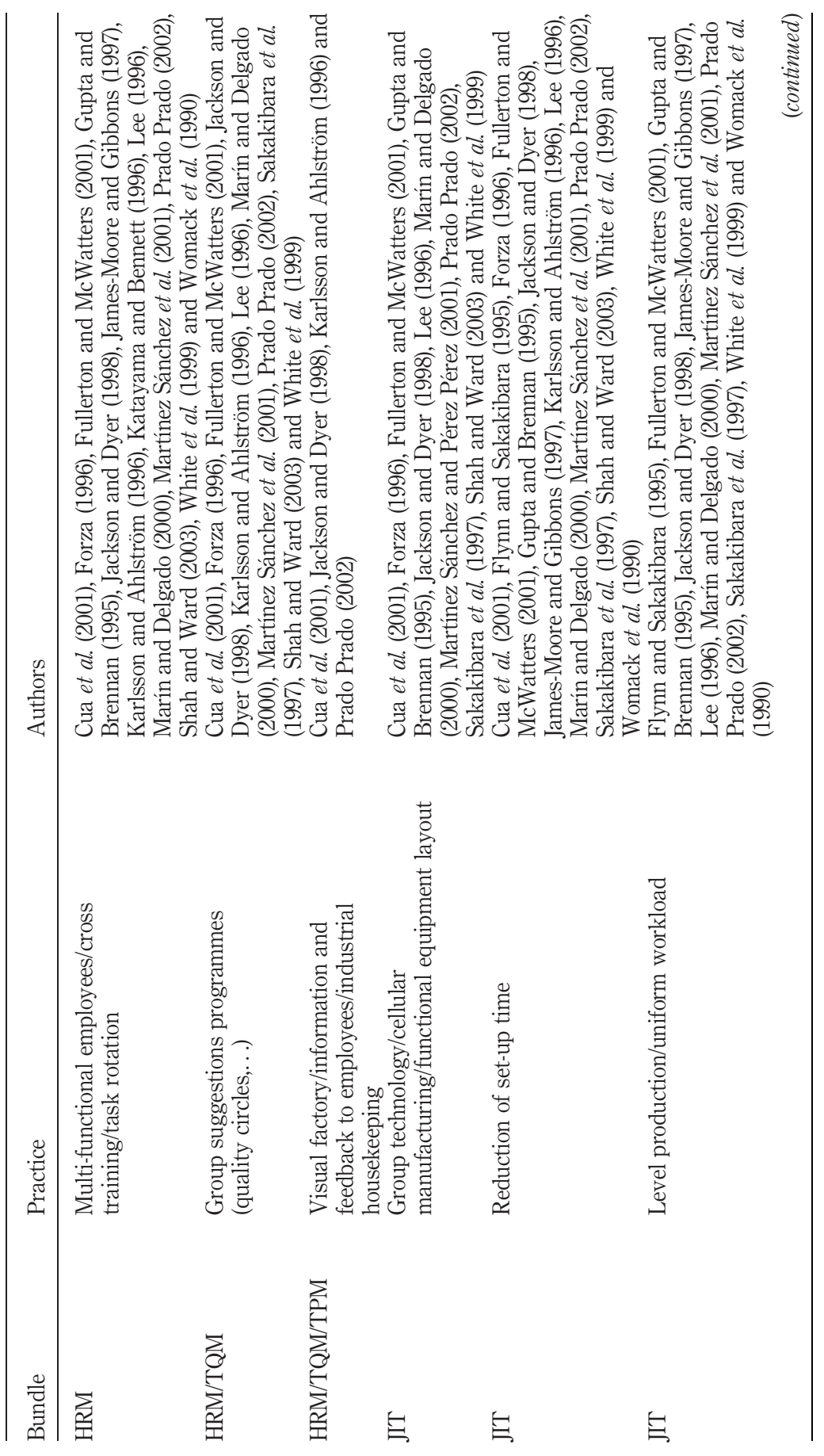




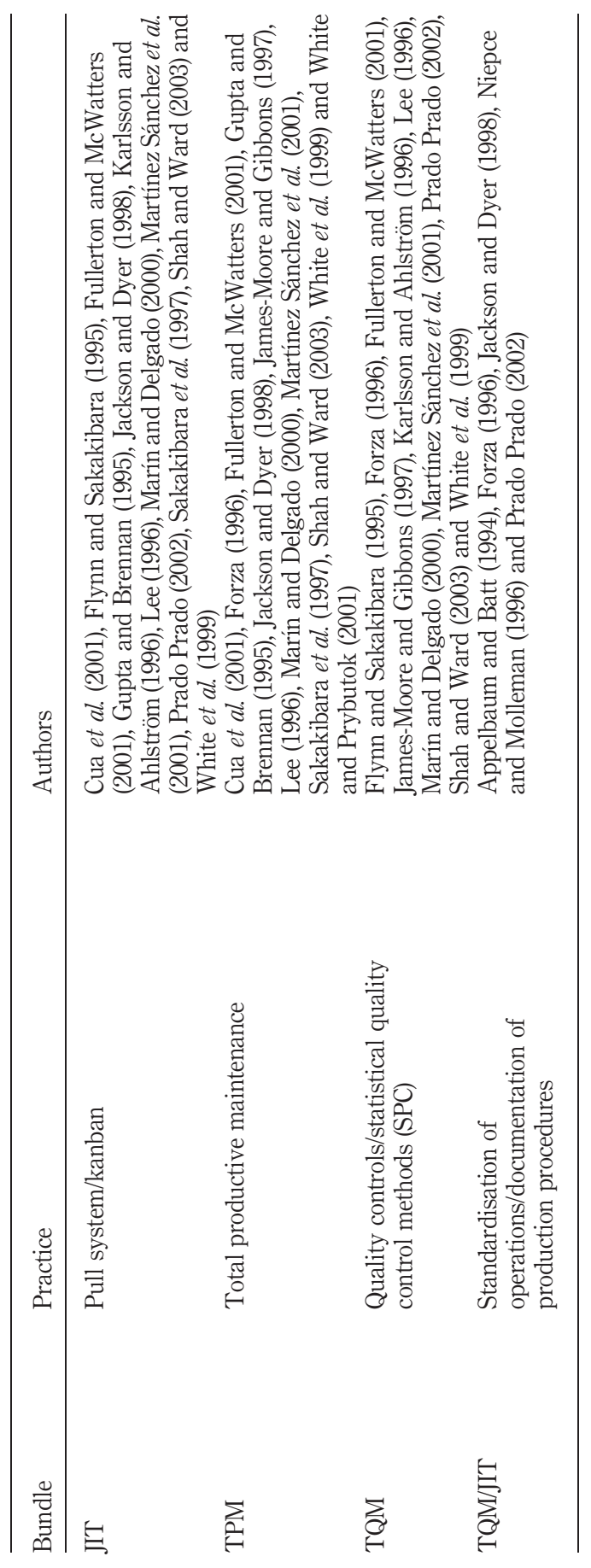

An empirical study of lean production

509

Table I. 
IJOPM

26,5

510 majority of firms are in fact small, not only in Spain but also in other countries (Lee, 1997; White et al., 1999). In addition, it seems obvious that there are some important differences between large and small enterprises with regard to factors that relate closely to the degree of LP implementation (Lee, 1997).

Researchers frequently define manufacturers' size by the number of employees or by sales volume, but when size is defined by number of employees (which is how we do it), there is no standard classification criterion. To take an example, some authors consider a business to be small if it has < 500 employees (Inman and Mehra, 1990; Schonberger, 1996), whereas Lee (1997) prefers 300 as the deciding number, and yet other authors fix the limit at 250 (Martínez Sánchez and Pérez Pérez, 2001; Shah and Ward, 2003; White et al., 1999). In some investigations, for instance, that of Martínez Sánchez and Pérez Pérez (2001, p. 1440), "small firms with less than 50 employees were excluded from the study because these companies are less likely to adopt LP practices".

Some researchers have found significant differences between large and small manufacturers in their degree of LP implementation. Thus, White et al. (1999) found that the degree to which quality circles, quality controls, TPM, set-up time reduction and kanban were implemented was higher in large businesses, whereas the multi-function employee concept was more firmly implanted in small ones. No significant differences were found with regard to group technology and uniform workload. Shah and Ward (2003) also observed that large plants are more likely to implement all but two practices (multi-function employees and TQM programmes) more extensively than small plants. Likewise Cooney (2002) states that the implementation of LP practices is less likely in small manufacturers. On the other hand though, some authors conclude that the degree of implementation of LP practices is unrelated to plant size (Finch and Cox, 1986; Inman and Mehra, 1990; Lee, 1997).

There is little data available for calculating the percentage of small businesses that are implementing each of the LP practices, and that data is to some extent conflicting. One reason for the divergence is that the samples used in the different studies do not correspond to the same population. According to White et al. (1999), the most used practices in small American manufacturing firms are multi-function employees (87 per cent), group technology (87 per cent), set-up time reduction (83 per cent) and quality controls (82 per cent). The least extensive are TPM (52 per cent), uniform workload (52 per cent), kanban (53 per cent) and quality circles (56 per cent). Inman and Mehra (1990) report similar data. Nevertheless, Lee (1997) paints a somewhat different picture in his study of small Korean firms. In his sample, the most commonly used instruments are quality controls (79 per cent) and set-up time reduction (68 per cent), whereas kanban (10 per cent) and group technology (36 per cent) are the least used.

In any case it is hard for small businesses to implement the whole set of practices as a system (Fullerton and McWatters, 2001; Gupta and Brennan, 1995; Lee, 1997). Rather they concentrate on a small subset, and without commitment to enlarging them in the future (Gupta and Brennan, 1995). For small firms it is better to select the tools they can afford and introduce them sequentially, starting with the easiest and least costly.

\section{LP and performance}

Firstly, we will consider studies that approach LP as a set of practices installed as a system. Quite a few authors claim that the benefits from introducing LP are much greater if advantage is taken of the synergies between the different LP practices (Cua 
et al., 2001; Fullerton and McWatters, 2001; Shah and Ward, 2003; White and Prybutok, 2001). Among the benefits most often mentioned are stock reduction, quality improvement, greater productivity and shorter lead time (Table II).

However, Fullerton and McWatters (2001) cite several cases where productivity, lead time or quality did not improve after LP was adopted. This is not surprising. As we said earlier, LP is a collection of related techniques and the different investigations have not all been dealing with the same ones. Bear in mind too that other researchers have observed how a piecemeal implementation approach often fails to improve operational performance indicators and that implementation of a single tool in isolation may even have a negative impact on them (Fullerton and McWatters, 2001). One possible explanation is that certain practices may indeed optimise a particular area of operations, but the local improvement does not necessary translate into an improvement at the overall level (White and Prybutok, 2001).

Secondly, we propose to analyse what happens when firms implement a set of techniques associated with a particular bundle (JIT, TQM, TPM or HRM). Our reason for doing so is that very few firms, especially small ones, try to introduce all the practices at the same time; they usually make it a step-by-step process (Cooney, 2002; Martínez Sánchez and Pérez Pérez, 2001). The conclusions in the various earlier studies are contradictory. For Sakakibara et al. (1997) the operational performance variations (inventory, on-time delivery and lead time) can be explained by implementation of practices associated with the TQM and HRM bundles, while the effects of TPM and JIT practices are not significant. Cua et al. (2001) believe that the effects of all four bundles are significant for explaining variations in quality and on-time delivery, although the use of HRM and TQM practices contributes more to performance than the other two. Flynn and Sakakibara (1995) conclude that the only significant explanation for the variation in quality performance is the implementation of HRM and customer relations practices, while TQM and JIT are not significant. Jackson and Dyer (1998) put forward

\begin{tabular}{|c|c|}
\hline & Authors \\
\hline Stocks reduction & $\begin{array}{l}\text { Billesbach (1994), Flynn and Sakakibara (1995), Fullerton and } \\
\text { McWatters (2001), Giffi et al. (1990), Gunn (1992), Jackson and Dyer } \\
\text { (1998), Lee (1997), Lowe et al. (1997), Martínez Sánchez and Pérez } \\
\text { Pérez (2001), Maskell (1995), Sakakibara et al. (1997), White et al. } \\
\text { (1999) and Womack et al. (1990) }\end{array}$ \\
\hline Quality improvements & $\begin{array}{l}\text { Billesbach (1994), Cua et al. (2001), Flynn and Sakakibara (1995), } \\
\text { Fullerton and McWatters (2001), Giffi et al. (1990), Gunn (1992), } \\
\text { Jackson and Dyer (1998), Krafcik (1988), Lee (1997), Lowe et al. } \\
\text { (1997), Sakakibara et al. (1997), Shah and Ward (2003), Wafa and } \\
\text { Yasin (1995), White et al. (1999) and Womack et al. (1990) }\end{array}$ \\
\hline Productivity (direct labour) & $\begin{array}{l}\text { Billesbach (1994), Giffi et al. (1990), Gunn (1992), Krafcik (1988), } \\
\text { Lowe et al. (1997), Shah and Ward (2003), White et al. (1999) and } \\
\text { Womack et al. (1990) }\end{array}$ \\
\hline Lead or cycle time & $\begin{array}{l}\text { Fullerton and McWatters (2001), Gunn (1992), Jackson and Dyer } \\
\text { (1998), Sakakibara et al. (1997), Shah and Ward (2003) and White } \\
\text { et al. (1999) }\end{array}$ \\
\hline On-time delivery & Cua et al. (2001), Lee (1997) and Sakakibara et al. (1997) \\
\hline Smaller batches & Lee (1997) \\
\hline Delivery time & Flynn and Sakakibara (1995) and Fullerton and McWatters (2001) \\
\hline
\end{tabular}

Delivery time

Flynn and Sakakibara (1995) and Fullerton and McWatters (2001)

\section{An empirical study of lean production}

511
Table II.

Operational performance benefits of LP implementation 
IJOPM

26,5

512 the opinion that HRM, TQM and TPM improve quality and lead time, whereas JIT improves lead time and reduces inventories. Lastly, Shah and Ward (2003) hold that all four bundles help to provide a significant explanation for the variation in operational performance (manufacturing cycle time, labour productivity, first pass yield, and customer lead time).

Thirdly, we have found very little research analysing the effect that a particular LP practice has on operational performance. Sakakibara et al. (1997) state that no isolated JIT practice except set-up time reduction is significant in explaining operational performance variations. Similarly, Cua et al. (2001) considers that no JIT practice in isolation can provide a statistically significant explanation of improvements in quality or on-time delivery; however, employee involvement, multi-function employees and TPM do have significant impact. For White and Prybutok (2001), in repetitive production systems the use of quality controls correlates with improvements in quality, productivity and stock levels; multi-function employees correlates with improvements in lead time, quality and productivity; and kanban correlates with improvements in lead time and quality.

Finally, when analysing the effect of LP practices on operational performance, different researchers (Cooney, 2002; De Toni and Tonchia, 1996; Fullerton et al., 2003; Inman and Mehra, 1990; Krafcik, 1988; Lowe et al., 1997; Williams et al., 1992, 1995) recommend using a series of different control variables, among which we would emphasise plant size, industry, product characteristics (manufacturability), vertical integration, capacity utilisation, model mix, automation level and market requirements.

\section{The ceramic tile industry in Spain}

According to data provided by ASCER (2003) (Spanish Association of Tile, Pavement and Ceramic Floor Tile Manufacturers), global production of 5,727 million square metres in 2001 makes the ceramic tile industry an important sector in the world economy. The main markets are China, Brazil, Spain, the USA and Italy. It is noteworthy that according to the 2001 data, Spain shares leadership with Italy in terms of manufacturing volume in the European Union, and these two countries share second place in the world after China. Spanish production in 2001 was 638 million square metres, a world market share of 11 per cent valued at 3,437 million euro. The Spanish industry employed 26,100 workers that year and there is a slight annual increase. The average number of workers is 87 per plant. There is some tendency towards concentration in the industry, that is to say fewer plants but each with more workers. Average worker productivity across the sector was approximately $2,078 \mathrm{~m}^{2} /$ month in 2001 and has remained practically unchanged between 1997 and 2003.

Yet in spite of the sector's importance both nationally and globally, very few studies have focused on analysing its importance for the world economy. We have found no especially relevant scientific publications on the topic from the viewpoint either of LP or the management of productive processes. The only paper which bears some relationship to our research is that of Rowley (1996). Rowley showed that the British and Italian ceramic tile industries are characterised by mass production. However, we have come across no data for Spain, nor can we be sure whether what Rowley concluded in 1996 is still valid. 
There are several motivations for the firms in this sector to introduce methods that give more flexibility to their production processes. The industry is exceptionally dynamic (Rowley, 1996). The demand is changing, and international competition is continually increasing due to globalisation (Porter, 1990). Moreover, in both Spain and Italy the manufacturers are concentrated in very specific geographical areas and so news about product and process innovations spreads quickly. Consequently, firms are under strong pressure to improve all the time if they want to have an advantage over their competitors (Porter, 1990). For that reason, Spanish firms are trying to consolidate in ever more profitable but demanding market segments so as to have a price advantage over the competition (Gil et al., 1999; Tomás Carpi et al., 1996). All this has led to a highly varied and constantly changing range of products, where design and quality play an essential role. Product life cycle is shortening and has dropped from ten to three or four years. Moreover, the number of formats and models is being expanded in an attempt to customise the goods on offer, while at the same time producers seek to reduce delivery times. Everything seems to indicate that this tendency is bound to increase in the future.

\section{Research objectives and hypothesis}

One would expect to find that firms in the tile industry have implemented LP tools to some extent. There are various reasons for supposing this. For one thing the sector is under pressure to improve continually, not only because of international competition but also because of internal competition within the geographical cluster. It is just such a situation that tends to promote the adoption of LP practices (MacDuffie and Frits, 1997), and thus LP practices are found in plants in all industries (Billesbach, 1994; Shah and Ward, 2003). The type of production process is not a bar to the use of the various LP practices, and in any case repetitive processes like ceramic tile manufacturing provide a more favourable environment (White and Prybutok, 2001) than non-repetitive processes. In addition, several authors (Inman and Mehra, 1990; Lee, 1997; White et al., 1999) say that multi-function employees, set-up time reduction and quality controls are generally more common than other practices in small businesses.

On the other hand, certain restrictions in the production system under examination make it unlikely that all LP practices would be installed to the same degree. One is the high degree to which the production lines are automated (Porter, 1990). Another is the constraints imposed by the firing process: the aim is to have the ovens functioning around the clock at maximum load, but model or format changes make it necessary to modify the parameters of the process, and the adjustments are difficult to foresee. Therefore, once the furnace adjustments have been made in such a way as to maintain product quality, the investment of effort has to be rendered viable by producing a certain minimum number of square metres of the same type. Actually, the batch size is very big - it amounts to at least the production of an entire shift. Added to this, the product itself has a very simple structure, so that there is no possibility of modular production. Hence, use of the LP practices most directly related to uniform workload (group technology, set-up time reduction and kanban) is unlikely in this sector.

This leads us to formulate the following hypotheses:

H1. The most used LP practices in this sector will be multi-function employees and quality controls, while the least used will be group technology, set-up time reduction and kanban.

\section{An empirical study of lean production}

513 
IJOPM

26,5

514
Moreover, as we commented above in the section on LP and plant size, we are of the view that LP practices can be most easily installed by very large firms (Fullerton and McWatters, 2001; Shah and Ward, 2003; White et al., 1999). Consequently, H2 may be formulated as follows:

H2. Larger firms will have installed LP practices to a higher degree than smaller ones.

Numerous studies have concluded that applying LP tools benefits a business. However, the benefits are greater if all the tools are installed, because there is a synergetic effect between them (White and Prybutok, 2001). In either case, firms can improve their operational performance (Callen et al., 2000; Cua et al., 2001; White and Prybutok, 2001). The implementation of one of the tools in isolation can also cause various business management indicators to improve (Lee, 1996), and so it is a strategy that can be recommended highly for SMEs (Lee, 1997; White et al., 1999), which do not usually possess the resources needed for implementing the complete system (Inman and Mehra, 1990). However, research that has focused on the operational performance effects of an isolated LP practice seems to indicate that these effects are only significant for a minority of the practices (Cua et al., 2001; Sakakibara et al., 1997). Faced with this difference of opinion, we have decided to formulate $H 3$ as follows:

H3. Companies that adopt an LP practice to a greater extent obtain better results in terms of quality, productivity, lead time or stocks.

To test this hypothesis we need to take account of the control variables proposed by previous researchers and mentioned in earlier sections of this paper. There are clearly advantages in limiting the research to firms in a single sector (MacDuffie, 1995; Shah and Ward, 2003). For one thing the homogeneity of the products and processes in the sector (Porter, 1990) makes it possible to hold a whole list of variables constant for the whole population (plant layout, process type, technology level, automation level, product complexity and manufacturability, manufacturing times and vertical integration). In addition, the concentration in a limited geographical area enables other control variables to be kept very similar for all the firms, e.g. worker training, collective bargaining, market requirements, salary structures and public investment. Under these conditions the only control variables we will need to analyse are plant size and capacity utilisation.

At the same time ceramic tile production is one of the leading sectors in Spanish industry. This gives us research access to a sufficiently large population, one that includes leading world-class companies. Finally, the fact that this population is concentrated in a nearby area to where the researchers are located makes it feasible to collect data directly from the producers at an acceptable cost for the research budget.

\section{Methodology}

Questionnaire construction

We developed a data collection questionnaire based principally on the work of White et al. (1999), Karlsson and Ahlstöm (1996) and Jackson and Dyer (1998) (see Appendix for a more detailed description). For the Spanish equivalents of terms we used Prado (2002) and Marín and Delgado (2000). In order to make the necessary adaptations to the 
peculiarities of the ceramic tile industry, we worked with technicians from ASCER and used consultants with many years of experience in the sector.

Once the questionnaire described below was outlined, it was pilot tested (for understanding of concepts, length, and importance of concepts in the industry) with three heads of production in three different ceramic tile companies. After this step, some modifications were made before reaching the definitive version. Meanwhile, we met with executives of the Castellon Chamber of Commerce and ASCER, both prestigious institutions in the industry, to present our project to them. Later, in June 2001, we held working sessions with the production management committees of firms associated with ASCER. The purpose of the meetings was to acquaint participants with the research and seek their support for carrying out the interviews. Approximately, 20 managers from different ASCER associate firms attended each session.

\section{LP practices measures}

We made several decisions intended to shorten interview time and thereby encourage better participation from plant management.

Firstly, we measured most of the LP practices by a single question on the survey instrument, as do other researchers (Fullerton and McWatters, 2001; White et al., 1999). We collected data for some of the variables during plant visits. That enabled us to nuance the variables and obtain more precision, for example, with quality controls. We included one variable specifying at the interview when the controls were applied, and another observing during the site visit whether statistical process control (SPC) was being applied in the lines. Another example is the splitting of visual factory into two variables: one for workplace housekeeping and another for shared graphic information.

Secondly, it became evident in the preliminary interviews that group technology, kanban and uniform workload would not show up in the sector. So instead of asking directly about group technology we decided to ask about cellular manufacturing layout as a proxy for it (White and Prybutok, 2001). In any case the latter could be observed directly during the plant visits and it was not really necessary to ask about it during the interviews. The kanban variable too was measured solely by plant visit observation. The observation guidelines were based on Cua et al. (2001) (Appendix). We left the uniform workload variable out of the research because it is not compatible with the attributes of this sector and is not directly observable during site visits. However, since it requires prior implementation of cellular manufacturing and set-up time reduction (Flynn and Sakakibara, 1995; Fullerton and McWatters, 2001; Suzaki, $1989,2000)$, the presence of these two variables can be exploited in order to estimate the likelihood that a firm may be working towards the installation of uniform workload too.

The criterion for scoring most of the replies was the degree of deployment of each LP practice, using a scale of 0 - none to 5 - complete implementation (Jackson and Dyer, 1998). Responses to the questions in the questionnaire show the opinion of the senior production manager whereas observations done by the researcher while visiting the factory are according to the guidelines described in the Appendix.

At a later stage we reclassified the manufacturers under each practice using a similar procedure to Fullerton and McWatters (2001) and Shah and Ward (2003): 0 non-adopters, 1-3 - low adopters, 4-5 - high adopters.

\section{An empirical study of lean production}

515 
IJOPM

26,5

516

\section{Performance measures}

The selected performance variables (internal quality, productivity, total stock and lead time) correspond to the most cited benefits associated with LP implementation and were used in previous research (Lowe et al., 1997; Shah and Ward, 2003; White et al., 1999; Williams et al., 1992, 1995) but the way of applying them was different in our questionnaire. Manufacturing performance was measured by objective (quantitative) variables in order to avoid perceptual bias (Flynn and Sakakibara, 1995; Fullerton and McWatters, 2001). These values were reported by the manufacturing manager.

Productivity was determined by combining the information from two questions: "Production in the month of June 2001 in square metres" divided by "Number of production and maintenance workers in the company". Internal quality was measured on the basis of the "percentage of prime quality products compared to the total manufactured". Lead time was defined as "average time between receiving an order in the production department and completing its manufacture”. And lastly, stock levels were measured as the sum of the days of inventory of finished goods, raw materials and work in process.

A manufacturing plant was classified as a high performer on a particular performance measure if its value on the measure was above average and similarly classified as a low performer if it was below average (Cua et al., 2001; Lowe et al., 1997). We also included a best-in-class plant classification that combined quality and productivity. We followed a procedure very similar to that proposed by Lowe et al. (1997) in their work, because it is relatively simple and very clear. A plant is best-in-class if it is simultaneously a high performer in both quality and productivity.

The interviewees were asked for data for June 2001. It should be emphasised that we were forced to this decision because we found in the initial interviews in the pilot phase that the number of manufacturing workers may vary considerably in the course of the year as a function of the amount of square metres to be produced. Moreover, the production data for the month of June was readily accessible and was recent in the minds of the interviewees, which made it a reliable basis for measurement. Furthermore, June is a normal month in production terms, comparable to any other month of the year except August, and perhaps September, when the shifts are changed due to holidays. The furnace operates normally and changes in the number of working shifts are rare.

For analysing the data we used non-parametric tests, since it is not necessary that they should conform to assumptions about the normal distribution of the variables.

\section{Sample}

At the time of our survey, ASCER had 208 member companies. Of these, we approached the ones that were located in the Valencian Autonomous Region (mainly in Castellon province) and were in the business of manufacturing single firing ceramic tiles (porous tiles, stoneware floor tiles and porcelain stoneware). Thus, the population was composed of 111 companies. Of these we eliminated the ones that belonged to the same business group and therefore maintained the same organisation structure and in some cases even the same manager (15 companies). This procedure reduced the sample of valid companies to 96 . The final response rate was 79.17 per cent (76 visits completed). 
The data was compiled between July and September 2001. The questionnaire was administered during a personal interview of 30 minutes average duration. Immediately after the interview, a visit to the facilities was made to obtain some of the data by direct observation. These visits took an average of 40 minutes per plant. Two interviewers took part in the process; they were trained and supervised by the main researchers, who accompanied them to the first interviews (approximately 10 per cent of all the interviews) and instructed them in how to apply uniform criteria. In any case, if we subsequently had any doubts concerning data provided by a company, we contacted the head of production by telephone to clarify them. Participating plants received a detailed profile of their own results and a sample means profile for comparison.

In addition, we conducted interviews with four consultants who were specialists in implementing LP practices in the tile industry, and also with ASCER technicians. The purpose was to discuss the results of our research.

\section{Results}

Implementation of LP practices

The companies in the sample manufacture large batches of only a few different products: between 100 and 200 models per company, distributed in few size formats. These products are technically homogenous and require the same manufacturing facilities. All the products go through a similar sequence of operations (preparation, moulding, drying, glazing, firing and classification), although some may by-pass a step that is not necessary for that product. The machines are placed in line, one after the other. After a batch of an item is manufactured, the machines are adjusted and a batch of a different item is made. Set-up times are usually long. Investment in machinery and automation is very high and there are hardly any manual processes involved, with the exception of line preparation for item changeover, internal transport and quality controls inspection. This description is valid for all the plants visited, as there are hardly any differences between them. It is a situation that agrees completely with what has been described in other studies (Assopiastrelle, 1998; Dalmau Porta and De Miguel Fernández, 1991; Porter, 1990). The workers are highly specialised and only perform the operations of their own section. Companies usually manufacture for stock, with the aim of achieving a high level of equipment use and reduction in unit costs. It is a manufacturing process situated midway between the categories of repetitive process (continuous flow manufacturing and assembly line process).

As we said earlier, all the firms examined have a very similar plant distribution and none can be typed as cellular manufacturing plants. Likewise the kanban system was absent from all of them. Some of them were using material requirements planning systems for production planning, but none was using a pull system. In Table III, we summarise the results of the rest of the variables. It is noteworthy that there were many firms that had not introduced set-up time reduction, multi-function employees, or graphs or panels for visual factory. On the other hand industrial housekeeping, standardisation of operations, TPM and quality controls were fairly widespread, especially the last two, which were to be found in all the firms in the sample. In addition, there were hardly any differences between the firms with regard to quality control, so that we can consider it to be a constant and treat it accordingly.

To check our H1 we use Friedman's non-parametric test to compare the related samples. The result shows that there are significant differences in the level of use of the
An empirical study of lean production

517 


\section{IJOPM \\ 26,5}

\section{8}

Table III.

Degree of implementation of LP practices

\begin{tabular}{lcccccccc}
\hline & \multicolumn{4}{c}{$0-5$ scale } & \multicolumn{5}{c}{ Low/high adopters } \\
Variable & Mean & SD & Min. & Max. & NoAd & LowAd & HighAd & $N$ \\
\hline Group technology & 0.00 & - & 0 & 0 & 76 & 0 & 0 & 76 \\
Pull system (kanban) & 0.00 & - & 0 & 0 & 76 & 0 & 0 & 76 \\
Reduction of set-up time & 0.45 & 1.11 & 0 & 5 & 60 & 13 & 3 & 76 \\
Multi-functional employees & 0.84 & 1.50 & 0 & 5 & 51 & 17 & 7 & 75 \\
Visual factory-graphs or panels & 0.97 & 1.72 & 0 & 5 & 56 & 13 & 10 & 76 \\
Visual factory-housekeeping & 1.82 & 1.08 & 0 & 5 & 4 & 67 & 5 & 76 \\
Statistical quality control & 1.86 & 1.72 & 0 & 5 & 33 & 37 & 6 & 76 \\
methods (SPC) & & & & & & & & \\
Group suggestions programmes & 1.91 & 2.39 & 0 & 5 & 44 & 4 & 28 & 76 \\
(quality circles,...) & & & & & & & & \\
Standardisation of operations & 2.70 & 2.27 & 0 & 5 & 24 & 15 & 37 & 76 \\
TPM & 3.93 & 1.33 & 1 & 5 & 0 & 27 & 49 & 76 \\
Quality controls & 4.93 & 0.25 & 4 & 5 & 0 & 0 & 76 & 76
\end{tabular}

Notes: NoAd, number of cases that do not implement the practice; LowAd, number of cases with low implementation; HighAd, number of cases with high implementation different LP programmes, and it enables us to order them from lesser to greater use (Table IV). In order to find out which variables are differentiated from the rest, we supplement the previous analysis with Wilcoxon tests to compare two related samples. Since, the variables are already ordered from lesser to greater levels of use, it is not necessary to compare all the possible pairings between the nine variables. For example, the differences between set-up time reduction and the use of SPC are significant, and consequently comparison with all the practices that are used more than SPC will be significant too. We have made a total of ten comparisons and corrected for the likelihood of type I error by the Bonferroni procedure.

The results indicate that there are no significant differences between the use of set-up time reduction, multi-function employees and graphs or panels for visual factory, nor are there differences between the degree of use of SPC, group suggestion

\begin{tabular}{lcl}
\hline & & $\begin{array}{l}\text { Programmes with similar degree } \\
\text { Rank average }^{\mathrm{a}}\end{array}$ \\
\hline Reduction of set-up time & 2.85 & $\mathrm{~A}$ \\
Multi-functional employees & 3.36 & $\mathrm{~A}$ \\
Visual factory-graphs or panels & 3.48 & $\mathrm{~A}$ \\
Statistical quality control methods (SPC) & 4.57 & $\mathrm{~B}$ \\
Group suggestions programmes & 4.69 & $\mathrm{~B}$ \\
(quality circles,...) & 4.99 & $\mathrm{~B}$ \\
Visual factory-housekeeping & 5.68 & $\mathrm{~B}$ \\
Standardisation of operations & 7.26 & $\mathrm{E}$ \\
TPM & 8.13 & $\mathrm{~F}$
\end{tabular}

Notes: ${ }^{a}$ Friedman for related samples. Significant rank difference $\left(\alpha<1\right.$ per cent); ${ }^{b}$ the significant differences occur between variables marked with different letters (significance level by Wilcoxon test with Bonferroni correction: $<10$ per cent)

\section{Table IV.}

Differences in the degree of implementation of LP practices 
programmes, industrial housekeeping and standardisation of operations. However, these four practices are more widely installed than the three that are less used. Lastly, the degree of use of TPM and quality control were significantly different from all the techniques previously mentioned and even showed a difference between themselves. Hence, it may be concluded that $H 1$ has been partially corroborated. Quality controls are implemented more than the other practices, while group technology, kanban and set-up time reduction are hardly used at all in the sector. Nevertheless, multi-function employee programmes are not as widespread as we had supposed, and TPM is more common than suggested by previous research.

\section{LP practices and plant size}

To group firms by size we have used as our variable the number of employees (mean $=152$ ). We adopt the classification that is usual in this type of research and according to which most of the firms studied may be considered small, i.e. with $<250$ workers. To adapt this criterion to the realities of the Spanish business fabric, and more specifically to the ceramic paving and coverings sector, we have set-up three additional subdivisions. We do this applying criteria employed in other studies (ASCER, 2003; Aster, 1997; Lee and Palmer, 1999; Martínez Sánchez and Pérez Pérez, 2001; Tomás Carpi et al., 1996). Thus, we have classified the 15 companies with $<50$ workers as the smallest in the sample, and the 12 with $>250$ employees as the biggest. Between these two extremes there were 37 with 51-150 employees and 12 with 151-250. This sample distribution corresponds broadly with that existing in the population, according to ASCER (2003) data. Generally speaking, the firms that make porcelain stoneware are the largest and most technologically advanced. It follows that their plants are usually the most recently built and most modern.

H2 has been partly supported. In Table V, we display the results from the Kruskall-Wallis test supplemented by the U-Mann-Whitney test to determine the groups between which significant differences appear. The main differences between large and small businesses showed up in the use of visual factory. The use of both industrial housekeeping and of graphs and panels to share line information with

\begin{tabular}{lccccc}
\hline & $<50$ & $50-150$ & $151-250$ & $>250$ & Sig. \\
\hline Visual factory-housekeeping & $32.03^{\mathrm{a}}$ & $33.45^{\mathrm{a}}$ & 44.67 & 56.00 & $* *$ \\
Visual factory-graphs or panels & $27.00^{\mathrm{b}}$ & 37.73 & 48.54 & 45.21 & $* *$ \\
TPM & $29.50^{\mathrm{c}}$ & 39.24 & 49.04 & 36.92 & + \\
Reduction of set-up time & 33.47 & 36.46 & 46.75 & 42.83 & + \\
Quality controls & 33.40 & 38.95 & 41.00 & 41.00 & + \\
Statistical quality control methods (SPC) & 31.00 & 41.45 & 38.08 & 39.21 & n.s. \\
Group suggestions programmes (quality circles,...) & 30.50 & 40.01 & 43.17 & 39.17 & n.s. \\
Standardisation of operations & 34.00 & 35.66 & 50.75 & 40.63 & n.s. \\
Multi-functional employees & 39.47 & 35.03 & 39.96 & 43.86 & n.s.
\end{tabular}

Notes: Sig., significance level on Kruskall-Wallis test: ${ }^{* *} \alpha<1$ per cent; ${ }^{*} \alpha<5$ per cent; $+\alpha<10$ per cent; ns: not significant; U-Mann-Whitney test; ${ }^{a}$ significant difference $(\alpha<5$ per cent after Bonferroni correction) when compared with firms with more than 250 workers; ${ }^{b}$ significant difference $(\alpha<5$ per cent after Bonferroni correction) when compared with the remaining firms; ${ }^{c}$ significant difference ( $\alpha<10$ per cent after Bonferroni correction) when compared with firms having 151-250 workers

\section{An empirical study of lean production}

519

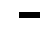


IJOPM

26,5

520 workers increases in keeping with the size of the firms. In the case of industrial housekeeping, the differences are significant when the firms with less than 150 employees are compared to the largest ( $>250$ employees). Likewise the use of panels is significantly less in firms with $<50$ workers than in the rest (Table II). As for the other variables, the differences are not so clear, although it can be observed that the degree of use is less in firms with $<50$ workers than in the rest. The only exception is the multi-function employee variable, which hardly varies whatever the size of the firm. The results also suggest that there are no significant differences in the degree of use of any of the LP practices between firms with more than 150 workers.

\section{Operational performance and LP practices}

Our last hypothesis $(H 3)$ is intended to check whether there is a correlation between the degree of use of LP practices and the results that firms achieve. We will first describe the operational performance variables and then analyse the control variables.

The companies surveyed achieved very high values of prime quality goods (averaging nearly 90 per cent) with very little variation between individual firms (Table VI). The average time between receiving an order for a product and finalising its manufacture is nearly three weeks. Firms' stocks of inventory (raw materials, work in process and finished goods) are, on average, equivalent to more than two months of manufacturing. Average monthly productivity is $4,155 \mathrm{~m}^{2}$. These last three variables show very considerable differences between companies. The only variable for which all the firms had data was internal quality. For the rest, many figures were not available because firms did not record such data in their information systems. We would especially point to the fact that 10 per cent of them did not know how much of a product they had in stock. The four variables examined are sufficiently independent of one another. The only significant correlations - and very low at that - are between stock and productivity (Spearman- $\rho=-0.339$ ), and between stock and quality (Spearman- $\rho=0.200$ ). Finally, of the 73 firms that had data on productivity and quality, 18 are high performance in both respects (best-in-class).

We have also looked at how far the selected control variables affect performance indicators. The two control variables applied are plant size (as described earlier) and capacity utilisation (mean 94 per cent; standard deviation 15.7 per cent). Since, the

\begin{tabular}{|c|c|c|c|c|c|c|c|}
\hline Variable & Mean & $\mathrm{SD}$ & Min. & Max. & LowPer & HighPer & $N$ \\
\hline \multicolumn{8}{|l|}{ Lead time (days between order } \\
\hline Stock (days) & 65.25 & 53.5 & 2 & 286 & 32 & 37 & \\
\hline $\begin{array}{l}\text { Internal quality (percentage of } \\
\text { prime quality goods) }\end{array}$ & 0.89 & 0.04 & 0.80 & 0.96 & 35 & 41 & \\
\hline $\begin{array}{l}\text { Productivity ( } \mathrm{m}^{2} / \text { month and } \\
\text { number of production and } \\
\text { maintenance employees) }\end{array}$ & 4,155 & 1,615 & 1,238 & 8,182 & 36 & 37 & \\
\hline Best-in-class & - & - & - & - & 55 & 18 & \\
\hline
\end{tabular}

Table VI.

Operational performance measures
Notes: LowPer, number of cases below average in this variable; HighPer, number of cases above average in this variable 
bottleneck in the production process is the furnaces, we calculate capacity utilisation as the quotient of:

- the square metres produced in June 2001 over; and

- the square metres potentially produced in function of the theoretical speed of the furnaces.

It turns out that there are no significant variations in lead time with respect to size of firm (Table VII). However, size does affect the other variables. We have completed the analysis by a U-Mann-Whitney test to compare, pair by pair, the different groupings of firms classed by size. Firms with $>250$ workers tended perhaps to have a top-quality index higher than did the rest, although the differences were not very big. What we can affirm with more certainty is that firms with $<50$ workers, and probably too those with 50-150 employees, show a lower inventory size than the other firms. Lastly, productivity is noticeably lower in firms with $>150$ workers.

Moreover, the greater the production capacity utilised, the better a firm's results in terms of quality and productivity. On the other hand, inventory and lead time levels rise as the plant utilisation rate increases (Table VIII).

In response to our third hypothesis $(H 3)$, we have drawn up several $2 \times 2$ tables and analysed them using the Mantel-Haenszel common odds ratio to examine the relationship between binary variables with size incorporated as the control variable. It would have been better if we had also integrated production capacity utilisation as a control variable, but only 33 firms provided it. An odds ratio of $<1$ denotes a negative

\begin{tabular}{lllccc}
\hline & $<50$ & $50-150$ & $151-250$ & $>250$ & Sig. \\
\hline Lead time & 31.17 & 39.04 & 29.72 & 37.88 & n.s. \\
Total stock & $21.33^{\mathrm{b}}$ & $34.57^{\mathrm{c}}$ & 46.72 & 45.36 & $* *$ \\
Internal quality & 40.30 & 32.72 & 41.63 & $50.96^{\mathrm{a}}$ & + \\
Productivity & $45.27^{\mathrm{c}}$ & $39.30^{\mathrm{c}}$ & 27.91 & 26.10 & +
\end{tabular}

Notes: Sig., significance level on Kruskall-Wallis test: $* * \alpha<1$ per cent; $* \alpha<5$ per cent; $+\alpha<10$ per cent; ns: not significant; U-Mann-Whitney test; ${ }^{a}$ significant difference $(\alpha<10$ per cent after Bonferroni correction) when compared with firms with less than 250 workers; ${ }^{\text {bignificant }}$ difference ( $\alpha<5$ per cent after Bonferroni correction) when compared with firms with more than 150 workers; ${ }^{c}$ significant difference ( $\alpha<10$ per cent after Bonferroni correction) when compared with firms with more than 150 workers

\section{An empirical study of lean production}

521

\begin{tabular}{lccrr}
\hline & & & & \\
& $\begin{array}{c}\text { Below-average } \\
\text { capacity utilisation }\end{array}$ & $\begin{array}{c}\text { Above-average } \\
\text { capacity utilisation }\end{array}$ & $\begin{array}{c}\text { Number of } \\
\text { cases }\end{array}$ & Sig. \\
\hline Lead time & 12.58 & 17.44 & 30 & + \\
Total stock & 11.38 & 17.56 & 29 & $*$ \\
Internal quality & 13.23 & 18.74 & 32 & + \\
Productivity & 12.73 & 18.36 & 31 & +
\end{tabular}

Notes: Sig., significance level: $* * \alpha<1$ per cent; $* \alpha<5$ per cent; $+\alpha<10$ per cent; ns: not significant
Table VII.

Kruskall-Wallis average ranking of operational performance by plant size

Nos: Sig, significance level: $* *<<1$ per 
IJOPM

26,5

522 correlation between the variables, and conversely a positive one when the ratio is $>1$ (White et al., 1999).

We cannot analyse the visual factory-housekeeping and quality control variables because almost all the firms fall into a single category (low adopters for the former and high adopters for the latter). Although we allowed for three levels in the degree of implementation variable for each LP practice (no adopter, low adopter and high adopter), we decided to combine the low and high adopters in a single category

(adopters) so as to ensure that boxes would have an expected frequency of $>5$. For the TPM variable there were 0 no-adopters, so we compare low adopters with high adopters.

The results of our analysis are summarised in Table IX. In most cases the degree of use of LP practices was not found to have any statistically significant influence on operational performance. However, the degree of use of SPC and of TPM correlate positively with best-in-class. The relationship is also positive between TPM and productivity. On the other hand, set-up time reduction correlates negatively with lead time. Likewise set-up time reduction and standardisation of operations correlate negatively with the inventory variable.

\section{Discussion}

Before discussing our findings, we would emphasise that our concern was to study the firms in the ceramic tile industry in Spain. For this reason, our conclusions cannot be extrapolated to other industries nor, probably, to other countries. Nevertheless, our sample has enabled us to pick out certain control variables, and hence we can attempt to explain the relationship between the size of a firm and the degree to which it implements an LP practice, and likewise the effect that the implementation exercises on operational results.

As our first finding, we verified that most LP-derived practices are still not widespread in this industry. It might be argued that the nature of the production process constitutes an insurmountable obstacle to implementing them. However, Billesbach (1994) studied the production of textile fibres in a continuous spinning operation that is strikingly similar to the generic process of tile manufacture, and he commented on the successful introduction of pull systems, visual management, TPM and multi-function employees. Therefore, there must be other control variables to explain the situation in the firms in our sample (Shah and Ward, 2003).

With demand so unstable, it would be complicated for firms to implement uniform workload, and therefore it is unlikely that kanban systems would appear (Williams et al., 1992, 1995). Implementations of cellular manufacturing and kanban tend to be closely associated, whereas the other JIT/TPM practices are only very loosely associated with them (Sakakibara et al., 1997). It must also be borne in mind that introducing cellular manufacturing as a first step towards group technology demands large investments in equipment and facilities (White and Prybutok, 2001). We have already indicated in our data that cellular manufacturing and pull systems are completely absent from the firms interviewed. As set-up time reduction programmes are closely related to these last two strategies (Dankbaar, 1997; Wafa and Yasin, 1995), it is not surprising that set-up time reduction is the next least used LP technique in the sector. Lastly, it has to be remembered that the sector is composed mainly of SMEs. It therefore follows that it has only limited resources to devote to introducing LP 


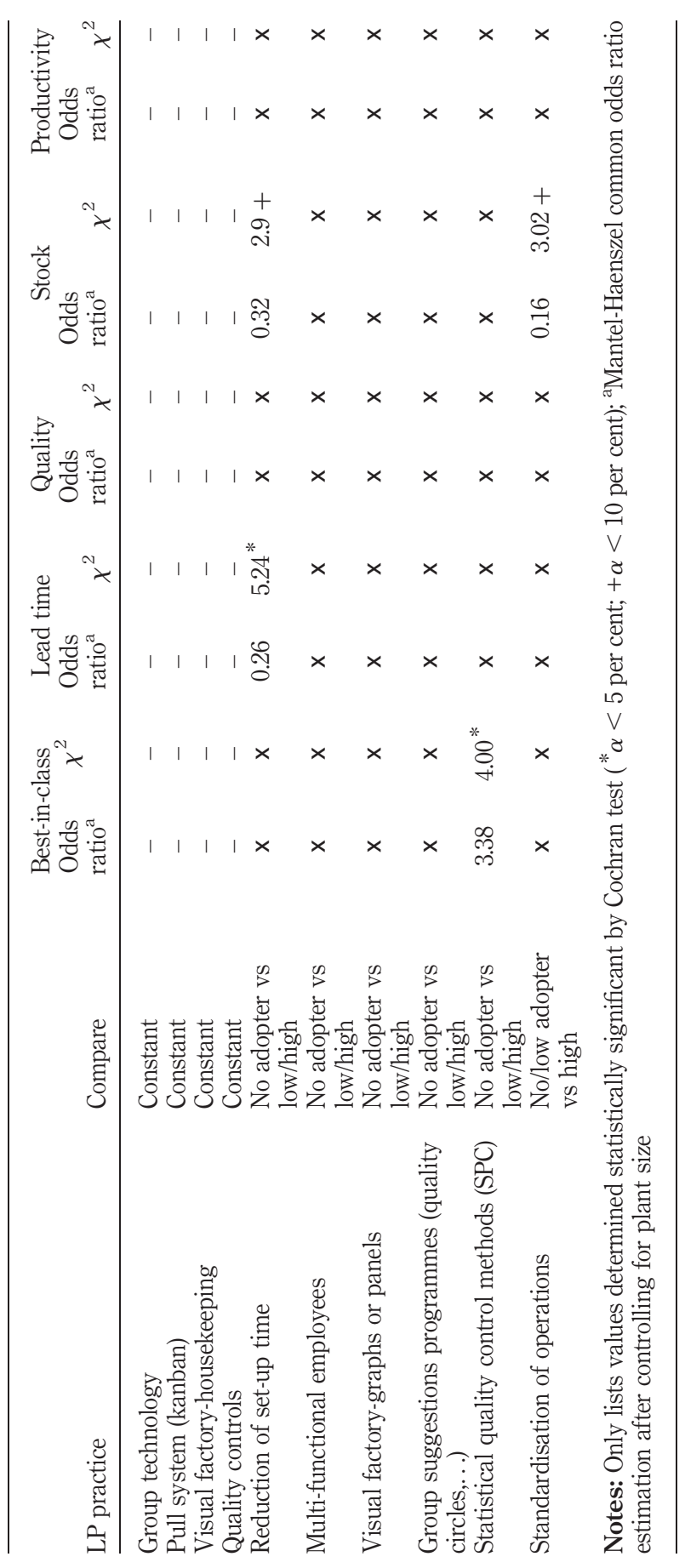

An empirical study of lean production

523

Table IX.

Relationship between LP practices and operational performance 
IJOPM

26,5

524 techniques (Inman and Mehra, 1990), and it will not embark on them unless it is convinced of the benefits that will accrue (Fullerton and McWatters, 2001) and is sure about which aspects of LP are suited to the specific circumstances of each firm (Finch and Cox, 1986).

The above findings are therefore to some extent predictable given the peculiarities of the sector. Even so, we have to admit that we were surprised to find so little use of multi-function employees, although we agree with White and Prybutok (2001, p. 122) that "implementation of multi-function employees in repetitive production systems is not an easy task". Multi-function employees is a practice that is basic for developing several other LP practices (TPM, set-up time reduction, uniform workload and cellular manufacturing). However, the only one of these practices that the firms in the sample are installing is TPM. On the face of it, it is surprising that there should be a high degree of use of TPM if there are no multi-function employees. What is happening is that the sector has developed a great deal of preventive maintenance (performed by specialised workers) and a few other aspects of TPM, but there is hardly any autonomous maintenance, which is where multi-function employees would be needed.

Among the more widespread LP practices are quality control at each process stage, standardisation of operations, SPC and TPM. With regard to quality control, improvements are developed by operations engineers or quality control staff. They have designed several devices in order to guarantee product quality, such as gauges or optical systems to discover flaws in finished products. Quality controls, standardisation of operations and SPC are basic tools in a group of businesses that have made a big commitment to competition based on quality products, whereas TPM is crucial in an automated process in which it is essential to ensure that the ovens function without interruption, because the energy costs would be enormous if it were necessary to close them down for repair. Industrial housekeeping is also used fairly extensively; it is one of the simplest and least investment-intensive tools (Lee, 1997). In addition, there is the consideration that plant cleanliness is quite an important factor in avoiding the contamination of products by impurities. As for group suggestion programmes, we believe they are installed more as a fashion rather than as a strategy to make the most of workers' experience in order to improve production processes. We tend to think this way because we have been able to observe that real worker participation in these programmes is very slight.

Besides the extent to which the various practices are deployed, we were interested in verifying the assertion of other researchers that LP implementation is greater in large companies than in small ones. We have found that the cluster of firms with 150-250 workers is no different in this respect from the cluster with $>250$. However, we have determined that, for five of the variables examined, there are significant differences between the smallest and the largest firms in the sample. The two visual factory variables and likewise TPM, set-up time reduction and quality controls are used more in firms with $>150$ employees than in the rest. It may be that standardisation of operations behaves the same way, but the relationship is not so clear cut and the differences are not statistically significant. Although we have also failed to find any significant difference between the degree of use of statistical quality controls or of group suggestion programmes, the data seem to indicate that there may be a tendency for them to be less implemented in very small firms $(<50$ employees) than in the others. On the other hand, use of multi-function employees does not seem to depend on 
the size of the firm. These findings are consistent with those of other researchers (Fullerton and McWatters, 2001; Shah and Ward, 2003; White et al., 1999). We can therefore surmise that within the small-business cluster in our sample the same relationships hold for comparison of small businesses ( $<250$ workers) with large ones ( $>500$ workers). Furthermore, the findings enable us to qualify Lee's (1997) pronouncement that plant size is no obstacle to LP implementation. Doubtless Lee is right when the category of "small businesses" includes some with over 150 workers, but firms with less than 50 workers probably suffer from certain restrictions that impede implementing LP practices, even single practices in isolation.

There may be several reasons explaining these differences between small and large firms. On the one hand, it is possible that large firms have more need of LP practices, due to the fact that their production processes are more complex, as well as the fact that they cannot base their coordination on informal communications. On the other hand, it is very likely that there are differences with regard to their resources available to deal with necessary changes. These resources can be financial, or could even be the time devoted to deployment of LP by managers and workers (Inman and Mehra, 1990; Shah and Ward, 2003). Finally, it is also possible that in small companies there is more frequently a lack of top management commitment or lack of knowledge about LP benefits or implementation procedures (Lee, 1997).

We have encountered hardly any relationships between the degree of use of LP practices and operational results. The only positive associations are between use of statistical quality controls and the combined variable "simultaneously best performer in both quality and productivity". This is probably due to the fact that we analyse the effect of practices individually and not as a whole system. If so, our findings are consistent with the proposition that the benefits of introducing LP tools will only be fully realised if it is done in an integrated way (Cua et al., 2001; White and Prybutok, 2001). Our findings also agree partially with those of Sakakibara et al. (1997), who believe that none of the JIT bundle practices in isolation, except set-up time reduction, is capable of explaining improvements in operational results. In our case, set-up time reduction has significant influence but not in the way that one would expect; we comment on this below.

Another factor is that several of the LP practices are used very little, which makes it unlikely that any effects would appear. It might be the case with multi-function employees; the positive effect suggested by several authors (Cua et al., 2001; White and Prybutok, 2001) is not reflected in our data. Yet another aspect is that some of the variables remained very constant, that is to say that the firms in the sample hardly varied in their use of them. This applies to group technology, kanban, housekeeping and quality control, and consequently we have not been able to analyse their connection with performance.

Some of our findings are counterintuitive. Contrary to what some researchers say (Cua et al., 2001; Suzaki, 1989), the firms that make most use of set-up time reduction are the ones that hold the most inventory and have the longest lead times. The former association may make sense, because the complete absence of pull systems suggests that firms take advantage of faster format changes to build up their stocks. The latter association may mean that only firms which have to cope with long lead times (probably because they lack sufficient production capacity) are interested in experimenting with these techniques. It is also true that set-up time reduction
An empirical study of lean production

525 
IJOPM

26,5

526 systems are employed very little, and even in firms that do use them there is probably an initial phase during which their benefits have yet to be realised. Another explanation, one that is consistent with White and Prybutok (2001), is that set-up time reduction is used in those processes where it is easiest to introduce them (presses or glazing) instead of in the firing process, which is the real bottleneck.

Last of all, the correspondence between standardisation of operations and larger inventory may also seem counterintuitive. However, the main objectives of this tool are to improve product quality in situations where there are manual operations - which is not the case in this sector - and improve operatives' productivity. That being so, if manufacture is done for inventory, any increase in productivity entails an increase in stock levels for as long as there is insufficient demand to absorb it. Our data seems to support this explanation, since there seems to be a correspondence between standardisation of operations and improved productivity (odds ratio: 1.9), although it is not statistically significant.

\section{Limitations}

Contrary to the research done by other researchers (Cua et al., 2001; Lee, 1996; Lowe et al., 1997; Shah and Ward, 2003; White et al., 1999), in our study all the firms are involved in the same activity. This makes it easier to form comparisons between plants. On the other hand, as it is a very homogeneous sector where operational practices are quickly transmitted from one competitor to another, certain variables vary very little between the firms in the sample, and this limits our ability to explain differences in operational results.

We have used quantitative values instead of measuring the production efficiency indicators with Likert type scales that might introduce an important subjective bias. For this reason, we believe that our work provides added value to previous studies that were based on mere subjective assessments from the people surveyed. Even so, we cannot be sure that our research is entirely free of the biases due to self-reported performance data and single respondents (Shah and Ward, 2003).

In addition, we have encountered problems in incorporating the capacity utilisation variable into our study. A great many values were not available because firms lacked the data we needed. We are concerned that this situation has prevented us from singling out some important effects and that it may be concealing a greater impact of LP practices on operational results than we have been able to demonstrate.

\section{Conclusions}

Most of the firms in the Spanish tile industry are small. Even so, there are differences in their behaviour. On the one hand, those with $<50$ workers use LP tools very little. On the other hand, the behaviour of firms with $>150$ workers is very similar to that of the medium-size and large firms in the population under study. In any event, LP deployment in the tile industry is generally low. Quality control and TPM have a high degree of implementation, but other practices (group technology, kanban, set-up time reduction, multi-function employees and graphs or panels for visual factory) are uncommon. We are of the opinion that variations in operational performance are hard to explain in this sector when an LP practice is only introduced in isolation.

The use of LP practices as described in the present study may reflect an operations management strategy that is well adapted to the particular limitations of the 
production system. So it may be that some traditional manufacturing imperatives are still important determinants of high performance. The economies of scale associated with high manufacturing volumes lead to high levels of efficiency in many industries. It appears to hold true in the ceramic tile industry too. As Rowley (1996) observed in his study, a good number of practices that are characteristic of mass production rather than of LP are still used in ceramic tile manufacturing. Rowley was referring to the British and Italian industries; to those the Spanish industry can now be added.

\section{An empirical study of lean production}

527

\section{References}

Andrés Romano, C. (2001), "Problemática de programación de producción en la empresa cerámica”, $\mathrm{PhD}$ thesis, Academic Department, Organización de empresas, Universidad Politécnica de Valencia.

Appelbaum, E. and Batt, R. (1994), The New American Work Place: Transforming Work Systems in the United States, ILR Press, New York, NY.

ASCER (2003), El sector español de fabricantes de baldosas ceramicas annual report, Asociación de Fabricantes de Azulejos, pavimentos y Baldosas Cerámicas, Castellón.

Assopiastrelle (1998), Sustainability Progress Report, Associazione nazionale dei produttori di piastrelle di ceramica e di materiali refrattari, Sassuolo.

Aster, F. (1997), Gestión de la Calidad y política de Márketing en las Empresas de la Comunidad Valenciana, Gráfiques BDM, Valencia.

Billesbach, T.J. (1994), “Applying lean production principles to process facility”, Production \& Inventory Management Journal, Vol. 35 No. 3, pp. 40-4.

Callen, J., Fader, C. and Kirnksky, I. (2000), "Just-in-time: a cross-sectional plant analysis", International Journal of Production Economics, No. 63, pp. 277-301.

Cooney, R. (2002), "Is ‘lean' a universal production system? Batch production in the automotive industry", International Journal of Operations \& Production Management, Vol. 22 Nos 9/10, pp. 1130-47.

Cua, K., McKone, K. and Schroeder, R.G. (2001), "Relationships between implementation of TQM, JIT, and TPM and manufacturing performance", Journal of Operations Management, Vol. 19 No. 6, pp. 675-94.

Dalmau Porta, J.I. and De Miguel Fernández, E. (1991), El azulejo. Estudio Sectorial, Banco de Crédito Industrial, Valencia.

Dalmau Porta, J.I., De Miguel Fernández, E. and Miquel Peris, S. (1993), Análisis estratégico de los sectores industriales y del turismo en la Comunidad Valenciana, Universidad Politécnica de Valencia, Valencia.

Dankbaar, B. (1997), "Lean production: denial, confirmation or extension of sociotechnical systems design?”, Human Relations, Vol. 50 No. 5, pp. 567-83.

De Toni, A. and Tonchia, S. (1996), "Lean organization, management by process and performance measurement", International Journal of Operations \& Production Management, Vol. 16 No. 2, pp. 221-36.

Finch, B.J. and Cox, J.F. (1986), "An examination of just-in-time management for the small manufacturer: with an illustration”, International Journal of Production Research, Vol. 24 No. 2, p. 329.

Flynn, B.B. and Sakakibara, S. (1995), "Relationship between JIT and TQM: practices and performance", Academy of Management Journal, Vol. 38 No. 5, p. 1325. 
IJOPM

26,5

528
Forza, C. (1996), "Work organization in lean production and traditional plants - what are the differences", International Journal of Operations \& Production Management, Vol. 16 No. 2, p. $42+$.

Fullerton, R.R. and McWatters, C.S. (2001), "The production performance benefits from JIT implementation”, Journal of Operations Management, Vol. 19 No. 1, pp. 81-96.

Fullerton, R.R., McWatters, C.S. and Fawson, C. (2003), "An examination of the relationships between JIT and financial performance”, Journal of Operations Management, Vol. 21 No. 4, pp. 383-404.

Giffi, C., Roth, A. and Seal, G. (1990), Competing in World-Class Manufacturing, Irwin, Homewood, IL.

Gil, I., Guarch, J.J. and Andrés, C. (1999), “La industria cerámica de la Comunidad Valenciana en el ámbito nacional y europeo", Boletin de la Sociedad Española de Cerámica y Vidrio, Vol. 38 No. 2, pp. 133-41.

Gunn, Th. (1992), 21st Century Manufacturing: Creating Winning Business Performance, OMNEO, Essex.

Gupta, S.M. and Brennan, L. (1995), "Implementation of just-in-time methodology in a small company", Production Planning \& Control, Vol. 6 No. 4, pp. 358-64.

Inman, A. and Mehra, S. (1990), "The transferability of just-in-time concepts to American small businesses", Interfaces, Vol. 20 No. 2, pp. 30-7.

Jackson, T. and Dyer, C. (1998), Diagnóstico corporativo: una herramienta para alcanzar la excelencia, TGP Hoshin, Madrid.

James-Moore, S.M. and Gibbons, A. (1997), "Is lean manufacture universally relevant - an investigative methodology", International Journal of Operations \& Production Management, Vol. 17 Nos 9/10, pp. 899ff.

Karlsson, C. and Ahlström, P. (1996), “Assesing changes toward lean production”, International Journal of Operations \& Production Management, Vol. 16 No. 2, pp. 24-41.

Karlsson, C. and Ahlström, P. (1997), "A lean and global smaller firm”, International Journal of Operations \& Production Management, Vol. 17 Nos 9/10, pp. 940ff.

Katayama, H. and Bennett, D. (1996), "Lean production in a changing competitive world: a Japanese perspective", International Journal of Operations \& Production Management, Vol. 16 No. 2, pp. 8-23.

Krafcik, J.F. (1988), “Triumph of the lean production system”, Sloan Management Review, Vol. 30 No. 1, pp. 41-52.

Lee, C.Y. (1996), "The applicability of just-in-time manufacturing to small manufacturing firms: an analysis", International Journal of Management, Vol. 13 No. 2, pp. 249-59.

Lee, C.Y. (1997), "JIT adoption by small manufacturers in Korea", Journal of Small Business Management, Vol. 35 No. 3, pp. 98-108.

Lee, K.S. and Palmer, E. (1999), "An empirical examination of ISO 9000-registered companies in New Zealand”, Total Quality Management, Vol. 10 No. 6, p. 887.

Lowe, J., Delbridge, R. and Oliver, N. (1997), "High-performance manufacturing - evidence from the automotive components industry", Organization Studies, Vol. 18 No. 5, pp. 783-98.

MacDuffie, J.P. (1995), "Human resource bundles and manufacturing performance: organizational logic and flexible production systems in the world auto industry", Industrial \& Labor Relations Review, Vol. 48 No. 2, p. 197.

MacDuffie, J.P. and Frits, K.P. (1997), "Changes in auto industry employment practices: an international overview”, in Kochan, T.A., Lansbury, R.D. and MacDuffie, J.P. (Eds), 
After Lean Production, Evolving Employment Practices in the World Auto Industry, ILR Press, London, p. 350.

Marín, F. and Delgado, J. (2000), "Las técnicas justo a tiempo y su repercusión en los sistemas de producción”, Economía Industrial, No. 331, pp. 35-41.

Martínez Sánchez, A. and Pérez Pérez, M. (2001), "Lean indicators and manufacturing strategies", International Journal of Operations \& Production Management, Vol. 21 No. 11, pp. 1433-51.

Martínez Sánchez, A., Pérez Pérez, M. and Urbina Pérez, O. (2001), "Flexibilidad organizativa y relación entre JIT y calidad total”, Alta Dirección, Vol. 35 No. 210, pp. 74-84.

Maskell, B. (1995), Sistemas de datos de industrias de primer nivel mundial, TGP-Hoshin, Madrid.

Niepce, W. and Molleman, E. (1996), "A case-study - characteristics of work organization in lean production and sociotechnical systems", International Journal of Operations \& Production Management, Vol. 16 No. 2, p. $77+$.

Porter, M.E. (1990), La ventaja competitiva de las naciones, Plaza \& Janés editores, Barcelona.

Prado Prado, J.C. (2002), "JIT (justo a tiempo), TQM (calidad total), BPR (reingeniería),...Distintos enfoques para incrementar la competitividad?”, Esic-market, No. 112, pp. 141-51.

Rowley, C. (1996), "Flexible specialisation: some comparative dimensions and evidence from the ceramic tile industry", New Technology, Work and Employment, Vol. 11 No. 2, pp. 125-36.

Sakakibara, S., Flynn, B.B., Schroeder, R.C. and Morris, W.T. (1997), "The impact of just-in-time manufacturing and its infrastructure on manufacturing performance", Management Science, Vol. 43 No. 9, p. 1246.

Schonberger, R.J. (1996), World Class Manufacturing: The Next Decade, Free Press, New York, NY.

Shah, R. and Ward, P.T. (2003), "Lean manufacturing: context, practice bundles, and performance", Journal of Operations Management, Vol. 21 No. 2, pp. 129-49.

Smith, A., Oczkowski, E., Noble, C. and Macklin, R. (2003), "New management practices and enterprise training in Australia", International Journal of Manpower, Vol. 24 No. 1, p. 31.

Sohal, A.S. and Egglestone, A. (1994), "Lean production: experience among Australian organizations", International Journal of Operations \& Production Management, Vol. 14 No. 11, pp. 35-51.

Suzaki, K. (1989), Modernes management im produktionsbetrieb, Carl Hanser Verlag, München.

Suzaki, K. (2000), Competitividad en fabricacion: técnicas para la mejora continua, TGP (Tecnologías de Gerencia y Producción), Madrid.

Tomás Carpi, J.A., Banyuls i Llopis, J., Cano Cano, E., Contreras Navarro, J.L., Gallego Bono, J.R., Picher i Campos, J.V., Such Juan, J. and Torrejón Velardiez, M. (1996), Cambio ténico-organizativo e impacto en el mercado de trabajo: La industria valenciana. Análisis de los sectores cerámico, calzado, textil y mueble, Informe de investigación. Grupo de Estudios sobre la dinámica Industrial y Laboral (GREDIL), Valencia.

Wafa, M.A. and Yasin, M.M. (1995), "The effect of situational constraints on workforce performance and JIT implementation: an empirical study", International Journal of Computer Applications in Technology, Vol. 8 Nos 3/4, pp. 139-44.

White, R.E., Pearson, J.N. and Wilson, J.R. (1999), "JIT manufacturing: a survey of implementations in small and large US manufacturers", Management Science, Vol. 45 No. 1, pp. 1-16.

White, R.E. and Prybutok, V. (2001), "The relationship between JIT practices and type of production system”, Omega, Vol. 29 No. 2, pp. 113-24.
An empirical study of lean production

529 
IJOPM

26,5

\section{0}

Williams, K., Haslam, C., Johal, S., Williams, J., Adcroft, A. and Willis, R. (1995), "Management practice or structural factors: the case of American versus Japan in the car industry", Economic and Industrial Democracy, Vol. 16, pp. 9-37.

Williams, K., Haslam, C., Williams, J., Cutler, T., Adcroft, A. and Sukhdev, J. (1992), “Against lean production”, Economy and Society, Vol. 21 No. 3, pp. 321-54.

Womack, J.P. and Jones, D.T. (1996), Lean Thinking. Banish Waste and Create Wealth in Your Corporation, Simon \& Schuster, New York, NY.

Womack, J.P., Jones, D.T. and Roos, D. (1990), The Machine that Changed the World, Macmillan, New York, NY.

Ybarra, J.A., Giner, J.M. and Santa Maria, M.J. (1996), "Una política industrial para la PYME. La experiencia de la cerámica española”, Economía Industrial, No. 308, pp. 175-85.

\section{Further reading}

SPSS-Inc. (2000), Statistical Analysis Using SPSS 10.0, SPSS-Inc., Chicago, IL.

\section{Appendix. LP variable metrics used in this research}

- Visual factory-industrial housekeeping (obtained by observation). Percentage of the plant where there are lines on the floor to distinguish work areas, corridors, etc. Is there a place for each thing? Is the plant free of unnecessary materials? ( 0 - no implementation, 1 - 1-20 per cent, 2 - 21-40 per cent..., 5 - 81-100 per cent).

- Visual factory-graphs and panels (obtained by observation). Percentage of the work areas where there are visible and updated graphs and panels showing the levels being reached in quality, productivity, breakage, problems detected in the area, etc. (0 - no implementation, 1 - 1-20 per cent, 2 - 21-40 per cent ..., 5 - 81-100 per cent).

- Group suggestions programmes (questionnaire). Is the production department currently organising groups where workers participate and make suggestions for improvement? (Suggestion systems, quality circles, problem solving groups, etc.) ( 0 - do not use, 3 - in process, 5 - fully implemented).

- TPM (questionnaire). What activities does the maintenance staff carry out? (1 - cleaning, greasing the machines and making minor repairs like changing fuses or replacing pulleys, 2 - major repairs, 3 - activities scheduled by a check list in a preventive maintenance programme, 4 - making improvements to the equipment to make it more resistant and in less need of maintenance, 5 - involvement in specifications or purchasing decisions for new equipment.)

- Standardisation of operations (questionnaire). Percentage of the work zones where there are constantly updated operations sheets specifying procedures, tools and materials, operating times, etc. $(0$ - no implementation, 1 - 1-20 per cent, 2 - 21-40 per cent . ., 5 81-100 per cent).

- Quality controls (questionnaire). When is a product quality controlled? (1 - no specific controls, 2 - when the product is completely finished, 3 - at the end of one of the processes, 4 - at the end of all the processes, 5 - while the processes are being carried out.

- Set-up time reduction (questionnaire). Percentage of changeover activities that have been analysed in detail with a view to cutting their duration: video analyses, time and motion studies, improvement proposals, toll selection, design of quick hook-ups, use of guides, etc. ( 0 - no implementation, 1 - 1-20 per cent, 2 - 21-40 per cent ..., 5-81-100 per cent). 
- Multi-function employees (questionnaire). What percentage of production operatives have received structured training for the different work positions (versatility)? $(0-$ none, 1 1-20 per cent, 2 - 21-40 per cent ..., 5 - 81-100 per cent).

- Statistical quality control methods (SPC) (obtained by observation). Is there any SPC (control diagrams updated for tolerances)? (0 - no implementation, 3 - data available only in a central computer, 5 - data available in workspaces).

- Group technology/cellular manufacturing/equipment layout (obtained by observation). Machines are grouped according to the product family to which they are dedicated $(0-$ no implementation, 1 - 1-20 per cent, $2-21-40$ per cent . ., 5 - 81-100 per cent).

- Pull system (kanban) (obtained by observation). They use kanban squares, containers or signals for production control (0 - no implementation, 1 - 1-20 per cent, 2 - 21-40 per cent .., $5-81-100$ per cent).

\begin{abstract}
About the authors
Tomas Bonavia is a Lecturer at the Department of Social Psychology in the University of Valencia (Spain). He has published articles in the areas of work and organizational psychology, and economic and consumer psychology. His main research topic is about participative management. He has participated in numerous international congresses on these subjects. Tomas Bonavia is the corresponding author and can be contacted at: tomas.bonavia@uv.es

Juan Antonio Marin is a Lecturer at the Department of Business Administration in the Polytechnic University of Valencia (Spain). He lectures on management, teamwork and management information systems. With regard to these areas he has also worked as a consultant for some companies in Spain and El Salvador (Central America). His main research fields are: participative management, lean production systems, performance evaluation and active learning in higher education. E-mail: jamarin@omp.upv.es
\end{abstract}

To purchase reprints of this article please e-mail: reprints@emeraldinsight.com Or visit our web site for further details: www.emeraldinsight.com/reprints 